\title{
Comparison Of Voltage Measurements on DC Gearbox Motor and PWM Voltage Based On Arduino Uno
}

\author{
Miftachul Ulum, Deni Tri Laksono*, and Dedi Tri Laksono \\ Electrical Engineering Department, University of Trunojoyo Madura, 69162 Bangkalan, Indonesia
}

\begin{abstract}
In this research, a DC motor tested using the L298 motor driver which is controlled by Arduino as the motor speed regulator and using the PWM method as a speed control signal generator for the DC motor. This research has several stages, namely literature study, arduino-based dc motor design, Arduinobased dc motor production, Arduino-based dc motor testing, then analysis of research results and conclusions are drawn. Testing on this Arduino-bas, ed DC motor was done with several experiments, by adjust the motor speed by setting the pwm value in the program listing section then measuring the pwm output on pin 9 of the Arduino Uno board. Then measurements were made on the right and left side of the motor. This experiment was carried out by setting the pwm value from 15 to 255 to determine the difference in the increase in the PWM output voltage and determine the voltage on the motor and determine the condition of the DC motor. The test results show that the initial motor moves when the set value of PWM = $45, \mathrm{PWM}$ voltage $=0.83 \mathrm{~V}$, right motor voltage $=1.53 \mathrm{~V}$, and left motor $=1.75 \mathrm{~V}$.
\end{abstract}

Keywords: PWM method, Arduino Uno, Voltage Measurements

\section{Introduction}

In this era, humans rely a lot on an electric motor for their daily needs. The use of electric motors has been widely carried out starting from household appliances, factory equipment, robotics, aircraft, computers and other electronic devices.

The development of advances in motor technology is expect to make the motor work reliably and efficiently. To achieve these expectations can finish by modifying some parts of the motor so that it can work optimally and efficiently. A dc motor is one type of electric motor that is currently often used.

In its use, a DC motor requires a direct voltage supply to the field coil, which converted into mechanical energy. The construction consists of two parts, namely a stator and a rotor. The field coil in a dc motor called the stator or the non-rotating part and the coil called the rotor or the rotating part.

If there is a rotation of the inner armature coil in a magnetic field, a voltage (electromotive force) will arise which changes direction in every half turn, so it is an alternating voltage.

In this study, an experiment carried out to control motor speed using PWM and an Arduino Uno-based L298 motor drive. The purpose of this research is to determine the efficiency of electric power that is connect to control a DC electric motor.

\footnotetext{
* Corresponding author : miftachul.ulum@trunojoyo.ac.id
}

\section{Reseach Method}

In this section, the research steps and explanations will be shown.

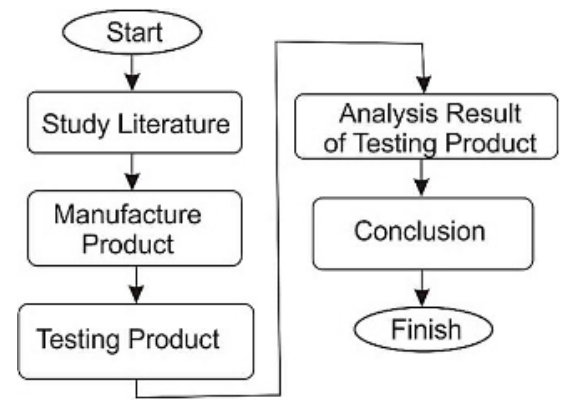

Fig. 1. Research Method

\subsection{Study Literature}

\subsubsection{Arduino}

Arduino is an open source and free software that used to build AVR programs. Arduino specially designed to support Arduino brand modules, kits, or circuit boards. Arduino has implemented an object-oriented programming model. The compiler that Arduino uses is an AVR-GCC Compiler.[3] 
Arduino is equipped with libraries that contain class definitions. With this library, building AVR application programs becomes easier. Arduino has also been equipped with an AVR program project editor and this editor was developed using the Java language.[3]

\subsubsection{Motor DC}

Moto DC motors require a direct voltage supply to the field coil converted into mechanical energy. In a dc motors there are two coils, namely the field coil whose function is to produce a magnetic field and the anchor coil serves as a place for the formation of an electromotive force (emf E).

If the current in the armature coil interacts with a magnetic field, a torque (T) will arise which will rotate a motor.[1]

\subsubsection{Driver Motor H Bridge}

$\mathrm{H}$-Bridge is a circuit used to control a DC motor. The $\mathrm{H}-$ Bridge transistor DC motor driver can control the direction of rotation of the DC motor in 2 directions and can be controlled using the PWM (Pulse Width Modulation) method as well as the TTL (High) and (Low) basic logic signal methods.[2]

DC Motor Driver with TTL logic method (0 and 1) or High and Low can only control the DC motor rotation direction in 2 directions without controlling the rotation speed (maximum speed). To control a DC motor in 2 directions with an H-bridge DC motor driver circuit above the control configuration on the input line is to provide input in the form of TTL logic to input lines A and $\mathrm{B}$ as follows:[2]

1. To control the direction of rotation in a clockwise direction is to provide logic TTL 1 (high) on input line A and logic TTL 0 (low) on input line B.[2]

2. To control the counterclockwise rotation direction is to provide logic TTL 1 (high) on input line B and logic TTL 0 (low) on input line A.[2]

\subsubsection{PWM}

Pulse witdh modulation (PWM) is one of the techniques used to control the power (power) usually regulates how much voltage will be used by sending a signal or pulse in the form of a signal. PWM in this study will be used to control the duty cycle on the signal that will be used to drive the motor so that the motor speed can be controlled.[4]ulse witdh modulation (PWM).[4]

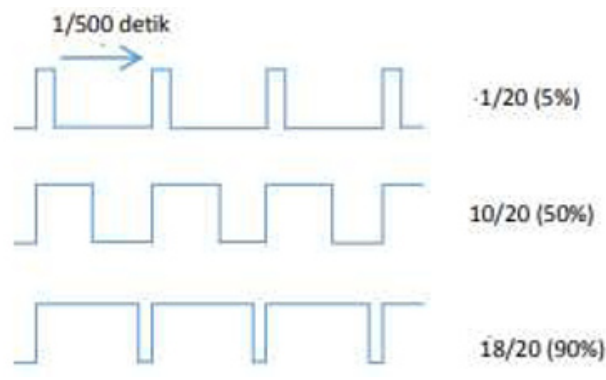

Fig. 2. Duty Cycle PWM

The form of the PWM signal can be seen in Figure 2 , a pulse is generated by the PWM signal every $1 / 500$ second, the pulse length will control the amount of voltage received by the motor, if no pulse is entered, the motor will not rotate until the next pulse arrives.[4]

\subsection{Manufacture Product}

The design of an Arduino-based dc motor and a 1298 motor driver is carried out using equipment that has been prepared in advance and is well designed, because to get the results of the research as desired.

The tools and materials needed in this design are arduino uno, L298N motor driver, two gearbox motors and a battery as a supply of electrical power to the circuit.

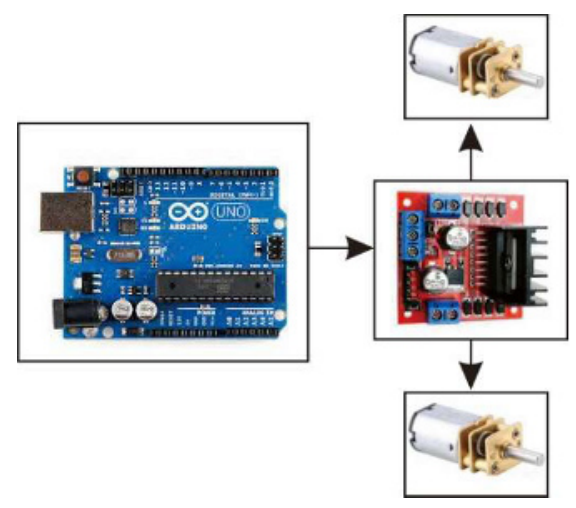

Fig.3. Diagram block system
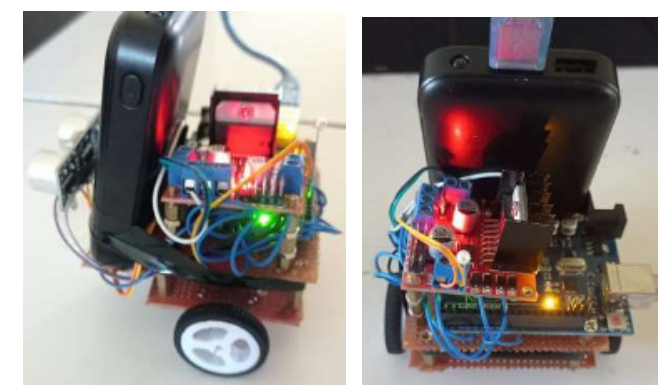

Fig.4. Product result after manufacturing 


\subsection{Testing Product}

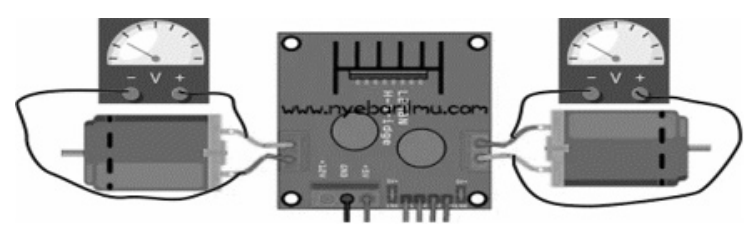

Fig. 5. Voltage measurement on the right and left dc motors

In this section, several measurement experiments are carried out, namely measuring the voltage when the PWM is set at a value of 15 to 255 . Then measurements are also made on the PWM output at pin 9 on the Arduino Uno board. This measurement is carried out to determine the characteristics of the voltage generated from PWM as a dc motor speed regulator.

\section{Result and Analysis}

The test in this study carried out several measurements, measuring the voltage at the PWM output at pin 9 on the Arduino Uno board, then measuring the voltage on the right dc motor and the left dc motor. The measurement results are shown in Figure .6.

Table 1. Motor test results with PWM

\begin{tabular}{|c|c|c|}
\hline PWM-Set & Right Motor & Left Motor \\
\hline 15 & Stop & Stop \\
\hline 25 & Stop & Stop \\
\hline 35 & Stop & Stop \\
\hline 45 & Run & Run \\
\hline 55 & Run & Run \\
\hline 65 & Run & Run \\
\hline 75 & Run & Run \\
\hline 85 & Run & Run \\
\hline 95 & Run & Run \\
\hline 105 & Run & Run \\
\hline
\end{tabular}

In Table 1. Shows the results of observing the condition of the initial motor rotating when the pwm value $=45$.

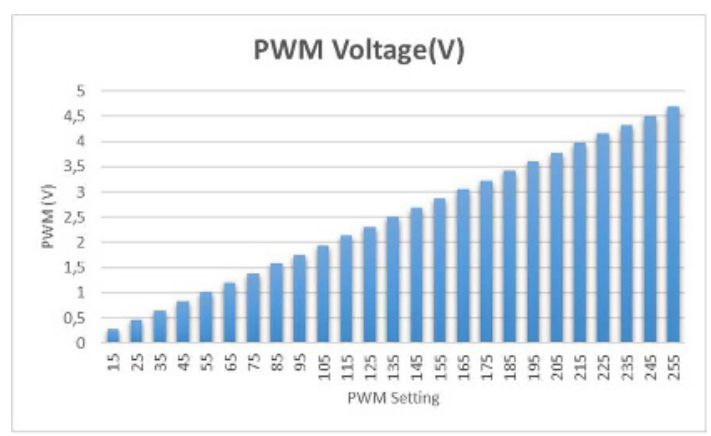

Fig.6. Graph of PWM output voltage measurement against the PWM setting value in the program listing

Figure 6 shows that when PWM is set at a value of 15 to 255 the output voltage will also experience a linear increase. It can be seen that the voltage measurement results increase following the increase in the PWM setting value, the smallest PWM voltage output shows a value of $<0.5 \mathrm{~V}$, and the largest PWM voltage measurement results $=<5 \mathrm{~V}$.

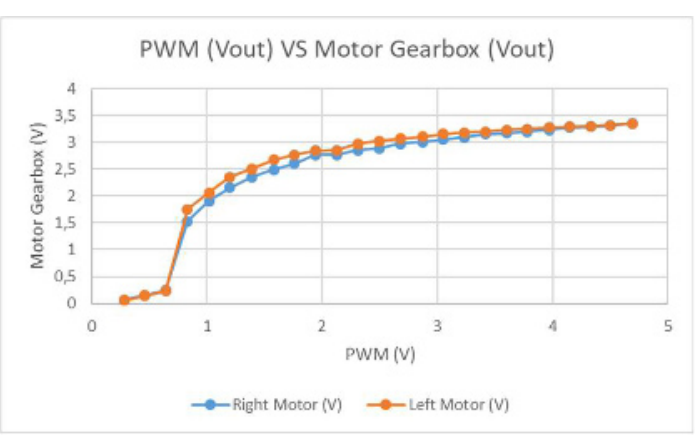

Fig.7 Graph of PWM comparison with right motor and left motor.

Figure 7, shows the graph of the comparison of the PWM voltage with the results of voltage measurements on the right and left dc motors. Garvik shows that the measurement results are in line with the results of the PWM voltage measurements and the voltage measurements on both motors. There are measurement results that increase sharply, which occurs when the PWM voltage is $<1 \mathrm{~V}$ and the right and left motor voltages are $<2 \mathrm{~V}$, where in the measurement results the right and left dc motor voltages suddenly increase from $0.5 \mathrm{~V}$ to $1.5 \mathrm{~V}$.

\section{Conclusion}

The results of this study, several conclusions can be drawn, namely:

1. In this study, the motor control uses the L 298 motor driver, using Arduino as the brain to process the PWM motor speed controller to generate pulses as input for the L298 motor driver.

2. The results show that the first time the motor rotates when the PWM is 45 , the voltage on the right motor $=1.53 \mathrm{~V}$, the left motor $=1.75 \mathrm{~V}$ and the PWM voltage $=0.83 \mathrm{~V}$.

3. The measurement results show a fairly linear increase from the smallest PWM at PWM 15 to PWM 255, namely at the PWM voltage output, right motor voltage and left motor.

\section{References}

1. Nalaprana Nugroho, Sri Agustina, “ANALISA MOTOR DC (DIRECT CURRENT) SEBAGAI PENGGERAK MOBIL LISTRIK" Journal Mikrotiga, Vol 2, No 1, (2015)

2. Evaristus Chandler Sunarto1, Bekti Yulianti 1, "Rancang Bangun Prototipe Alat Angkut Helikopter Berbasis Arduino", Jurnal Tesla, Vol 20, No 2, Oktober (2018) 
3. Adewasti, Emilia Hesti, Sholihin, Sarjana, "SISTEM KENDALI ROBOT HAND GESTURE BERBASIS WIRELESS”, Jurnal Surya Energy Vol 3, No 1, (2018).

4. Suhendra Tonny, et, al, "Kendali Kecepatan Motor DC dengan Metode Pulse Width Modulation menggunakan N-channel Mosfet", Jurnal Sustainable: Jurnal Hasil Penelitian dan Industri Terapan, Vol 07, No. 02, (2018).

5. N. Tadrist and H. Zeroug, "Development of brushless DC motor drive system for teaching purposes using various PWM control techniques for speed control," 2014 IEEE 15th Workshop on Control and Modeling for Power Electronics (COMPEL), (2014), pp. 1-4, doi: 10.1109/COMPEL.2014.6877150.

6. P. H. Karnavar and V. R. Jisha, "Harmonic Reduction and Power Factor Improvement of BLDC Motor Drive System Using a Selective Harmonic Elimination PWM Based Controller," 2020 International Conference on Power, Instrumentation, Control and Computing (PICC), (2020), pp. 1-5, doi: 10.1109/PICC51425.2020.9362432.

7. K. J.P., N. Withana, K. Gallage, J. Wijayarathna and A. Wijethilake, "Development of a Programmable Mechanical Motor Loading Unit using a DC Motor," 2019 Moratuwa Engineering Research Conference (MERCon), (2019), pp. 211-215, doi: 10.1109/MERCon.2019.8818829.

8. M. P. Ciurys, "Brushless DC motor with a vane pump built in and with speed control using PWM method," 2017 18th International Symposium on Electromagnetic Fields in Mechatronics, Electrical and Electronic Engineering (ISEF) Book of Abstracts, (2017), pp. 1-2, doi: 10.1109/ISEF.2017.8090704.

9. X. Yao, Y. Zhang and X. Jiang, "A novel PWM_OFF_PWM mode for braking operation of brushless DC motor," IECON 2017 - 43rd Annual Conference of the IEEE Industrial Electronics Society, (2017), pp. 1711-1716, doi: 10.1109/IECON.2017.8216290.

10. Y. Tan, A. Setiaji, E. Wismiana, M. Yunus, M. R. Effendi and A. Munir, "IoT System Implementation for ATmega328 Microcontroller Based Home Door Control," 2019 IEEE 5th International Conference on Wireless and Telematics (ICWT), (2019), pp. 1-4, doi: 10.1109/ICWT47785.2019.8978214.

11. M. F. Fahmi, A. S. Rohman, H. Hindersah and E. M. I. Hidayat, "Sliding Mode Position Control of BLDC Motor with Nonlinear Load Torque in a Locomotive Simulator Platform," 2019 2nd International Conference of Intelligent Robotic and Control Engineering (IRCE), (2019), pp. 7884, doi: 10.1109/IRCE.2019.00023.

12. M. F. Fahmi, A. S. Rohman, H. Hindersah and E. M. I. Hidayat, "Position Control of BLDC Motor with Nonlinear Load Torque in a Locomotive Simulator Platform," 2019 IEEE 9th International Conference on System Engineering and Technology (ICSET), (2019), pp. 221-226, doi: 10.1109/ICSEngT.2019.8906385.

13. A. I. Aulia, M. Faswia Fahmi, H. Hindersah, A. S. Rohman and E. Muhammad Idris Hidayat, "Implementation of Motion Cueing and Motor Position Control for Vehicle Simulator with 4DOF-Platform," 2019 6th International Conference on Electric Vehicular Technology (ICEVT), (2019), pp. 40-45, doi: 10.1109/ICEVT48285.2019.8994028.

14. Deni Tri Laksono, et, al,“ Automatic Coffee Maker Berbasis Arduino Mega”, Jurnal Triac, Vol 7, No 1, (2020), DOI: https://doi.org/10.21107/triac.v7i1.7207 